\title{
Mitigation of water restriction effects on soybean with biofertilizer: metabolic and
}

\section{stomatal conductance changes}

\author{
Mitigação dos efeitos da restrição hídrica em soja com biofertilizante: alterações metabólicas e de \\ condutância estomática
}

Mitigación de los efectos de la restricción hídrica en soya con biofertilizante: alteraciones metabólicas y de conductancia estomática

Harielly Marianne Costa Marques

ORCID: https://orcid.org/0000-0001-5906-5472 Universidade Federal do Paraná, Brazil E-mail: hariellymarques@hotmail.com Ely Cristina Negrelli Cordeiro ORCID: https://orcid.org/0000-0002-0025-3687 Universidade Federal do Paraná, Brazil E-mail: elycordeiro@outlook.com Juliana de Oliveira Amatussi ORCID: https://orcid.org/0000-0002-8025-4638 Universidade Federal do Paraná, Brazil E-mail: julianaamatussi@gmail.com Gabriel Bocchetti de Lara

ORCID: https://orcid.org/0000-0002-9090-6812 Universidade Federal do Paraná, Brazil E-mail: gabrielbdelara@ hotmail.com

Gilda Mógor

ORCID: https://orcid.org/0000-0002-4480-4487 Universidade Federal do Paraná, Brazil E-mail: gildamogor@gmail.com

Lais Cristina Bonato Malmann Nedilha

ORCID: https://orcid.org/0000-0003-3741-5384 Universidade Federal do Paraná, Brazil E-mail: lais.cristina19@live.com

Átila Francisco Mógor

ORCID: https://orcid.org/0000-0003-4199-9079 Universidade Federal do Paraná, Brazil E-mail: atila.mogor@ufpr.br

\begin{abstract}
The demand for soybean has increased in the international market, and water restriction is an important factor in reducing its yield. Therefore, the development of technologies aimed to reducing the damage caused by water stress becomes strategic. Thus, the objective was to demonstrate the role of the amino acid L-glutamic acid in mitigating water stress in soybean plants. A study was conducted in a greenhouse using soybean plants in vegetative stage subjected to water restriction and foliar applications of biofertilizer obtained from bacterial fermentation, containing $25 \%$ of the amino acid L-glutamic acid, sprayed three days before the imposition of water restriction and when the substrate moisture reached $50 \%$ of the water retention capacity (WRC). Stomatal resistance was determined throughout the days and three collections of plant material were carried out: at the beginning of water restriction, one and four days after rehydration for biochemical and enzymatic analyses. Plants that were supplied with biofertilizer at the beginning of water restriction showed lower stomatal resistance, while plants that received application three days before 50\% WRC showed increases in sugar accumulation, in free amino acids and proline content, and in nitrate reductase and peroxidase enzymes activity, consequently, reducing lipids peroxidation, mitigating the effects of oxidative stress.
\end{abstract}

Keywords: Amino acids; Antioxidant enzymes; Glycine max; Oxidative stress.

\section{Resumo}

A soja tem crescente demanda no mercado mundial, sendo a restrição hídrica um importante fator de redução da sua produtividade. Portanto, o desenvolvimento de tecnologias visando a mitigação dos danos causados pelo estresse hídrico torna-se estratégico. Desse modo, objetivou-se demonstrar o papel do aminoácido ácido L-glutâmico na 
mitigação do estresse hídrico em plantas de soja. O estudo foi conduzido em casa de vegetação com plantas de soja em estágio vegetativo submetidas a restrição hídrica com aplicações foliares de $1 \mathrm{ml} \mathrm{L}^{-1}$ de um biofertilizante obtido de fermentado bacteriano contendo $25 \%$ do aminoácido ácido L-glutâmico, 3 dias antes da imposição da restrição hídrica e quando a umidade do substrato atingiu $50 \%$ da capacidade de retenção de água (CRA). Determinou-se a resistência estomática no decorrer dos dias e procederam-se três coletas de material vegetal: no início da restrição hídrica, um e quatro dias após a reidratação para analises bioquímicas e enzimáticas. As plantas que receberam aplicação do biofertilizante no início da restrição hídrica apresentaram menor resistência estomática, enquanto as plantas que receberam aplicação 3 dias antes de CRA50\% apresentaram aumentos no acúmulo de açúcares, na atividade da enzima redutase do nitrato, de aminoácidos livres, no teor de prolina e na enzima peroxidase. Por consequência, verificou-se a redução dos danos causados pela restrição hídrica com redução da peroxidação lipídica nos tratamentos com aplicação do biofertilizante, mitigando os efeitos do estresse oxidativo em plantas de soja.

Palavras-chave: Aminoácidos; Enzimas antioxidantes; Glycine max; Estresse oxidativo.

\begin{abstract}
Resumen
La soya tiene una demanda creciente en el mercado mundial, siendo la restricción hídrica un factor importante en la reducción de la productividad. Por ende, el desarrollo de tecnologías orientadas a mitigar los daños causados por el estrés hídrico se torna estratégico. Por lo tanto, el objetivo fue demostrar el papel del aminoácido ácido L-glutámico en la mitigación del estrés hídrico en plantas de soya. El estudio se llevó a cabo en invernadero con plantas de soya en etapa vegetativa sometidas a restricción hídrica con aplicaciones foliares de $1 \mathrm{~mL} \mathrm{L-1}$ de un biofertilizante obtenido a partir de fermentación bacteriana conteniendo $25 \%$ del aminoácido L-glutámico, 3 días antes de imponer la restricción hídrica y cuando la humedad del sustrato alcanzó el 50\% de la capacidad de retención de agua (CRA). Se determinó la resistencia estomática con el pasar de los días y se realizaron tres recolecciones de material vegetal: al inicio de la restricción hídrica, un y cuatro días después de la rehidratación para análisis bioquímicas y enzimáticas. Las plantas que recibieron aplicación de biofertilizante al inicio de la restricción hídrica presentaron menos resistencia estomática, mientras que las plantas que recibieron aplicación tres días antes de CRA50\% mostraron incrementos en la acumulación de azucares, en la actividad de la enzima reductasa de nitrato, de aminoácidos libres, en el contenido de prolina y en la enzima peroxidasa. Consecuentemente, se corroboró la reducción del daño causado por la restricción hídrica, con una reducción de la peroxidación lipídica en los tratamientos con aplicación de biofertilizante, mitigando los efectos del estrés oxidativo en plantas de soya.
\end{abstract}

Palabras clave: Aminoácido; Enzimas antioxidantes; Glycine max; Estrés oxidative.

\title{
1. Introduction
}

Soybean (Glycine max) is economically the most important legume, providing more than a quarter of the total protein for human food and animal feeding (Liu et al., 2020). However, water restriction is the main limiting factor for soy production worldwide (Anda et al., 2020). Global climate changes, driven by greenhouse gas emissions, negatively impacted the rainfall regime, causing drought in several agricultural regions (Trenberth et al., 2014; Mousavi-Derazmahalleh et al., 2018).

Damages caused by water stress in plants are related to the direct reduction of photosynthesis with stomatal closure resulting in a reduction in stomatal conductance and $\mathrm{CO}_{2}$ fixation (Silva et al., 2021), with a consequent reduction in crop yield (Xu et al., 2010). Plants subjected to water restriction accumulate reactive oxygen species (ROS) (Gill \& Tuteja, 2010) that can rapidly react with a wide diversity of cell constituents and oxidize them; these include proteins, DNA, RNA, and cause lipid peroxidation of membranes. (Taiz et al., 2017). Thus, finding solutions that mitigate the effects of water stress on plants is necessary.

According to Brazilian regulation, biofertilizers are products that contain active components or organic agents, free of agrochemicals, capable of acting directly or indirectly, on all or part of the plants, improving the performance of the production system. Among the allowed sources, amino acid biofertilizers are products obtained by fermentation or hydrolysis of natural organic materials (Brasil, 2020).

The amino acid L-glutamic acid can be obtained through the fermentation of sugarcane molasses by the bacterium Corynebacterium glutamicum. In plants, L-glutamic acid is a precursor of several metabolic processes (Rhodes \& Handa, 1989), and can act as a proline precursor (Forde \& Lea, 2007), an important osmoprotectant, being an antioxidant defense and signaling molecule (Hayat et al., 2012). The effect of L-glutamic acid obtained through fermentation by Corynebacterium 
glutamicum applied to plants leaves was reported improving chlorophylls and stimulating amino acid metabolism (Röder et al., 2018).

Thus, the aim of this study was to evaluate the physiological and biochemical effects of foliar applications of biofertilizer containing $25 \%$ of L-glutamic acid in soybean plants subjected to water restriction at different application times.

\section{Methodology}

The experiment was conducted at the Laboratory of Biofertilizers at the Federal University of Paraná (UFPR) within the geographic coordinates of latitude $25^{\circ} 25^{\prime} \mathrm{S}$, longitude $49^{\circ} 08^{\prime}$, and altitude $930 \mathrm{~m}$. The scientific method used in this work was a quantitative research, with the application of statistic methods to analyze the collected data (Pereira et al., 2018). Cultivation was carried out in a greenhouse, using soybean cultivar $58 \mathrm{i} 60$ RSF IPRO, in 3-L pots kept on benches and filled with a substrate composed of pine bark, peat, and expanded vermiculite, whose chemical analysis indicated: $\mathrm{pH}(\mathrm{CaCl} 2)=$ 6,63, pH SMP $=7,03, \mathrm{Al}^{+3}=0 ; \mathrm{H}^{+}+\mathrm{Al}^{+3}=2,31 \mathrm{cmol} \mathrm{dm}{ }^{-3}, \mathrm{Ca}^{2+}=12,34 \mathrm{cmol} \mathrm{dm}^{-3}, \mathrm{Mg}^{2+}=3.52 \mathrm{cmol} \mathrm{dm}^{-3}, \mathrm{~K}^{+}=1.95$ $\mathrm{cmol} \mathrm{dm}^{-3}, \mathrm{P}=193,81 \mathrm{mg} \mathrm{dm}^{-3}, \mathrm{C}=55,21 \mathrm{~g} \mathrm{dm}^{-3}$; soil base saturation $=88,5 \%$ and $\mathrm{CEC}=20,12 \mathrm{cmol} \mathrm{dm}^{-3}, \mathrm{Cu}=1,95 \mathrm{mg}$ $\mathrm{kg}^{-1}, \mathrm{Mn}=31,80 \mathrm{mg} \mathrm{kg}^{-1}, \mathrm{Fe}=29,77 \mathrm{mg} \mathrm{kg}^{-1}, \mathrm{Zn}=2,30 \mathrm{mg} \mathrm{kg}^{-1}, \mathrm{~B}=0,34 \mathrm{mg} \mathrm{kg}^{-1}, \mathrm{~S}=141,12 \mathrm{mg} \mathrm{kg}^{-1}$. Also, $3 \mathrm{~cm}^{3}$ of expanded vermiculite was added over the top of the pots.

A biofertilizer obtained from sugarcane molasses fermented by the bacterium Corynebacterium glutamicum was used, containing $300 \mathrm{~g} \mathrm{~L}^{-1}(25 \% \mathrm{w} / \mathrm{w})$ of the amino acid L-glutamic acid and $48 \mathrm{~g} \mathrm{~L}^{-1}$ of nitrogen (4\% w/w) (Vorax®, Microquímica - Tradecorp). Applications were made with a pressurized sprayer with a constant pressure of 40 psi and a spray volume of 400 $\mathrm{mL}$ per treatment.

\subsection{Irrigation}

Irrigation control was performed with the use of the gravimetric method (daily weighing of experimental units), considering the mass of substrate and water, and by recharging the water lost through evapotranspiration. The determination of the water retention capacity (WRC) of the substrate was performed by sampling the total amount of substrate contained in the pot and saturated with water. After remaining at rest until the total interruption of the free water drain, the saturated substrate was weighed. Then, the substrate was taken to a forced circulation oven, at a temperature of approximately $65^{\circ} \mathrm{C}$, for drying. The determination of the substrate WRC was performed through the difference between the mass of the saturated substrate and the dry substrate.

The pots were locally irrigated with individual drippers per pot and maintained at $80 \%$ of the WRC until the V4phenological stage (40 days after emergence) in all treatments. After this period, the water-restricted treatments were no longer irrigated. In two days, the WRC showed 50\%, establishing itself as a condition of water stress, being kept in this humidity for another three days. After this period, the plants were rehydrated to $80 \%$ WRC.

\subsection{Treatments}

The treatments consisted of foliar sprays of $1 \mathrm{ml} \mathrm{L}^{-1}$ of the biofertilizer: (i) over plants without water restriction (3NSE); (ii) three days before moisture reaching 50\%WRC (B3S); (iii) application when reaching 50\%WRC(BAS); (iv) the positive control without application of the biofertilizer with moisture reaching 50\%WRC (PC); (v) absolute control, without biofertilizer application and without water restriction (AC). 


\subsection{Stomatal conductance}

Through put the period in which the plants were maintained with 50\% WRC and after rehydration, stomatal conductance measurements were performed through stomatal resistance $\left(\mathrm{cm} \cdot \mathrm{s}^{-1}\right)$ (Mcdermitt, 1990). The measurements were made using the Porometer equipment, Li-cor brand, inc. model LI-1600, always in the morning and on the same leaf.

\subsection{Biochemical analyses}

Three collections were carried out for biochemical analysis: The first collection corresponds to the third day of the experiment, performed one day after 50\% WRC which refers to three days after BNS (biofertilizer applied over plants without water restriction) and B3S (biofertilizer applied three days before moisture reaching 50\%WRC), and one day after BAS (application when reaching 50\%WRC). The second collection corresponds to the fifth day of the experiment and one day after the reestablishment of irrigation for $100 \%$ WRC. The third collection was performed on the eighth day, four days after rehydration. Leaves were collected in the morning, in the middle third of the plant, then frozen and macerated in liquid nitrogen.

Pigments analyzes was determined adding $0.3 \mathrm{~g}$ of plant material to $1.7 \mathrm{~mL}$ of $80 \%$ acetone with $0.1 \% \mathrm{CaCO}_{3}(\mathrm{w} / \mathrm{v})$ (Lichtenthaler, 1987; Pompelli et al., 2013). After centrifugation (9335 g for 2 seconds) the supernatant was used for spectrophotometer readings at 663,647 and $470 \mathrm{~nm}$.

The extraction of total sugars were obtained by acid hydrolysis and subsequent reaction with DNS. The reading was performed in a spectrophotometer at $540 \mathrm{~nm}$ (Maldonade et al., 2013).

For nitrate reductase, the methodology of (Jaworski, 1971) was used and the absorbance used was 540nm. Total free amino acids were extracted according to (Winters et al., 2002) and the colorimetric reaction was carried out according to (Magné \& Larher, 1992) with reading in a spectrophotometer at $570 \mathrm{~nm}$. Soluble proteins were determined using the methodology described by (Bradford, 1976). Proline content was determined using the method of (Bates et al., 1973), with 3\% sulfosalicylic acid, $1 \%$ ninhydrin solution, and toluene. The reaction was read in a 520-nm spectrophotometer.

The peroxidase enzyme activity was determined according to (Teisseire \& Guy, 2000) with the formation of purpurogallin measured in a UV-visible spectrophotometer at $430 \mathrm{~nm}$. The superoxide dismutase enzyme was determined according to (Giannopolitis \& Reis, 1977) with the formation of the blue compound (formazan) in the presence of light through NBT photoreduction, determined using the reading in a spectrophotometer at $560 \mathrm{~nm}$, in addition to readings carried out in the dark. The catalase enzyme was determined using enzymatic extract, sodium phosphate buffer, and $\mathrm{H}_{2} \mathrm{O}_{2}$ with absorbance readings at $240 \mathrm{~nm}$ (Peixoto et al., 1999).

Lipid peroxidation was determined according to the technique described by (Heath \& Packer, 1968), cited by (Devi \& Prasad, 1998) using thiobarbituric acid and trichloroacetic acid with absorbance readings in a UV-visible spectrophotometer at 560 and $600 \mathrm{~nm}$.

\subsection{Experimental design}

The experimental design was completely randomized with four replications $(n=4)$ in a factorial scheme 5 (treatments) x 8 (days/readings) for stomatal conductance values, and a factorial scheme 5 (treatments) x 3 (collections) for biochemical and enzymatic analysis. Each replication consisted of two pots containing three plants each. The data obtained were tested by Bartlett and ANOVA, compared by Tukey's test ( $p$ <0.05) using SISVAR statistical program (Ferreira, 2019). 


\section{Results}

Values of the stomatal resistance (SR) pointed to interactions between the factors can be seen in Table 1 . The comparison among the values over the days in each treatment did not show any changes in treatments BNS and AC (absolute control), while B3S showed a gradual increase in SR over the first, second, and third days indicating less opening of the stomata. As of the 4th day, the rehydration led to a reduction in SR, which remained unchanged until the last determination (8th day).

Table 1. Stomatal Diffusive Resistance values (measured with the soy leaf porometer) device soybean (Glycine max) for a period of eight days in 50\% WRC and $80 \%$ WRC with or without application of amino acids.

\begin{tabular}{lcccc}
\hline Days & $\mathbf{1}^{\mathbf{0}}$ & $\mathbf{2}^{\mathbf{0}}$ & $\mathbf{3}^{\mathbf{0}}$ & $\mathbf{4}^{\mathbf{0}}$ \\
BNS & $1,53 \pm 0,28 \mathrm{aA}$ & $1,34 \pm 0,24 \mathrm{cA}$ & $1,35 \pm 0,24 \mathrm{dA}$ & $1,28 \pm 0,23 \mathrm{cA}$ \\
B3S & $1,65 \pm 0,30 \mathrm{aD}$ & $11,42 \pm 2,07 \mathrm{bC}$ & $36,43 \pm 6,61 \mathrm{aA}$ & $27,00 \pm 4,90 \mathrm{aB}$ \\
BAS & $1,47 \pm 0,27 \mathrm{aD}$ & $12,27 \pm 2,23 \mathrm{bA}$ & $8,49 \pm 1,54 \mathrm{cB}$ & $4,72 \pm 0,86 \mathrm{bC}$ \\
PC & $2,13 \pm 0,39 \mathrm{aB}$ & $26,27 \pm 4,47 \mathrm{aA}$ & $26,25 \pm 4,76 \mathrm{bA}$ & $26,23 \pm 4,76 \mathrm{aA}$ \\
AC & $1,76 \pm 0,32 \mathrm{aA}$ & $2,54 \pm 0,46 \mathrm{cA}$ & $1,39 \pm 0,25 \mathrm{dA}$ & $1,27 \pm 0,23 \mathrm{cA}$ \\
& & & $\mathbf{7}^{\mathbf{0}}$ & $\mathbf{8}^{\mathbf{0}}$ \\
Days & $\mathbf{5}^{\mathbf{0}}$ & $\mathbf{6}^{\mathbf{0}}$ & $1,12 \pm 0,20 \mathrm{aA}$ & $1,64 \pm 0,30 \mathrm{aA}$ \\
BNS & $1,22 \pm 0,22 \mathrm{aA}$ & $1,04 \pm 0,19 \mathrm{aA}$ & $1,25 \pm 0,23 \mathrm{aD}$ & $1,63 \pm 0,30 \mathrm{aD}$ \\
B3S & $1,32 \pm 0,24 \mathrm{aD}$ & $1,14 \pm 0,21 \mathrm{aD}$ & $2,11 \pm 0,38 \mathrm{aD}$ & $1,76 \pm 0,32 \mathrm{aD}$ \\
BAS & $0,93 \pm 0,17 \mathrm{aD}$ & $0,95 \pm 0,17 \mathrm{aD}$ & $2,34 \pm 0,42 \mathrm{aB}$ & $1,66 \pm 0,30 \mathrm{aB}$ \\
PC & $1,74 \pm 0,32 \mathrm{aB}$ & $1,08 \pm 0,20 \mathrm{aB}$ & $2,18 \pm 0,40 \mathrm{aA}$ & $2,30 \pm 0,42 \mathrm{aA}$ \\
AC & $1,93 \pm 0,35 \mathrm{aA}$ & $2,43 \pm 0,44 \mathrm{aA}$ & & \\
\hline
\end{tabular}

BNS- Application of $1.0 \mathrm{~mL} \mathrm{~L}^{-1}$ of amino acid three days before water stress (80\%WRC); B3S - Application of $1.0 \mathrm{~mL} \mathrm{~L}^{-1}$ amino acid three days before water stress (50\%WRC); BAS - Application of $1.0 \mathrm{~mL} \mathrm{~L}^{-1}$ amino acid on the day of water stress (50\% WRC); PC - Positive control (without application and 50\% WRC); AC - Absolute control (without application and 80\% WRC). Means followed by the same letter do not differ statistically in Tukey's test $(\mathrm{p} \leq 0.05)$. Uppercase letters $=$ compare lines (treatments over days). Lowercase letters $=$ compare columns (treatment per day).

Source: Authors.

Treatment PC (positive control) showed an increase in SR on the second day in 50\%WRC, and subsequent reduction on the third, which intensified from the fourth day by rehydration, which was maintained until the end.

The PC treatment showed an increase in SR from the second day in 50\%WRC, with a reduction from the fifth day, that is, the day after rehydration, which is the natural response of adaptation of the soybean cultivar 58i60 RSF IPRO to the reduction in the availability of water, while BAS promoted the reduction of SR even during water restriction, and B3S right after rehydration (fourth day), as effects of the biofertilizer application.

The comparison among the SR between treatments each day showed that differences occurred from the second day in $50 \%$ WRC, until the fourth day, in treatments B3S and BAS, showing SR around $60 \%$ lower than that of the PC on the second day, while on the third and fourth days, BAS presented an SR respectively of 60 and $82 \%$ lower than the PC treatment, as an effect of the biofertilizer application in the maintenance of stomatal conductivity during 50\%WRC in the BAS treatment and immediately after the period of water restriction in the B3S treatment.

Contents of the leaf pigments showed interactions between treatments and collection days as shown in Table 2. The comparison between chlorophyll $a$ content over the days in each treatment showed that BNS did not change, whereas PC and AC showed a reduction during the collections, indicating that this effect was not related to water restriction, as it also occurred 
in the AC. In treatments with water restriction and application of biofertilizer, B3S showed a reduction on the fifth and eighth days in relation to the third day, while BAS had no alteration on the levels.

Table 2. Pigments $\left(\mathrm{mg} \mathrm{g}^{-1}\right)$ of 45-day-old soybean (Glycine max) leaves, kept in pots, subjected to water stress and amino acid application in collections at 3 different days.

Third day Fifth day Eighth day

(a) Chlorophyll $a$

$\begin{array}{cccc}\text { BNS } & 0,458 \pm 0,04 \mathrm{bA} & 0,448 \pm 0,04 \mathrm{aA} & 0,407 \pm 0,03 \mathrm{aA} \\ \mathrm{B} 3 \mathrm{~S} & 0,497 \pm 0,05 \mathrm{abA} & 0,353 \pm 0,03 \mathrm{bcB} & 0,327 \pm 0,03 \mathrm{bB} \\ \text { BAS } & 0,352 \pm 0,03 \mathrm{cA} & 0,303 \pm 0,03 \mathrm{cA} & 0,325 \pm 0,03 \mathrm{bA} \\ \text { PC } & 0,467 \pm 0,04 \mathrm{abA} & 0,347 \pm 0,03 \mathrm{bcB} & 0,304 \pm 0,03 \mathrm{bC} \\ \text { AC } & 0,529 \pm 0,05 \mathrm{aA} & 0,402 \pm 0,03 \mathrm{abB} & 0,274 \pm 0,03 \mathrm{bC}\end{array}$

(b) Chlorophyll $b$

$\begin{array}{cccc}\text { BNS } & 0,166 \pm 0,02 \mathrm{abcA} & 0,187 \pm 0,02 \mathrm{aA} & 0,132 \pm 0,02 \mathrm{aB} \\ \mathrm{B} 3 \mathrm{~S} & 0,181 \pm 0,02 \mathrm{abA} & 0,137 \pm 0,02 \mathrm{bcB} & 0,104 \pm 0,01 \mathrm{abC} \\ \text { BAS } & 0,138 \pm 0,02 \mathrm{cA} & 0,114 \pm 0,02 \mathrm{cAB} & 0,089 \pm 0,01 \mathrm{bcB} \\ \text { PC } & 0,162 \pm 0,02 \mathrm{bcA} & 0,114 \pm 0,02 \mathrm{cB} & 0,038 \pm 0,01 \mathrm{dC} \\ \text { AC } & 0,199 \pm 0,03 \mathrm{aA} & 0,150 \pm 0,02 \mathrm{bB} & 0,056 \pm 0,01 \mathrm{cdC}\end{array}$

\section{(c) Chlorophyll total}

$\begin{array}{cccc}\text { BNS } & 0,624 \pm 0,05 \mathrm{abA} & 0,675 \pm 0,06 \mathrm{aA} & 0,464 \pm 0,04 \mathrm{aB} \\ \mathrm{B} 3 \mathrm{~S} & 0,685 \pm 0,06 \mathrm{aA} & 0,536 \pm 0,04 \mathrm{bcB} & 0,431 \pm 0,04 \mathrm{abC} \\ \text { BAS } & 0,479 \pm 0,04 \mathrm{cA} & 0,430 \pm 0,04 \mathrm{dAB} & 0,375 \pm 0,03 \mathrm{bcB} \\ \text { PC } & 0,580 \pm 0,05 \mathrm{bA} & 0,461 \pm 0,04 \mathrm{cdB} & 0,312 \pm 0,03 \mathrm{cC} \\ \text { AC } & 0,706 \pm 0,06 \mathrm{aA} & 0,552 \pm 0,05 \mathrm{bB} & 0,360 \pm 0,03 \mathrm{bcC}\end{array}$

(d) Carotenoid

\begin{tabular}{cccc} 
BNS & $0,624 \pm 0,06 \mathrm{aA}$ & $0,219 \pm 0,02 \mathrm{aB}$ & $0,203 \pm 0,02 \mathrm{aC}$ \\
$\mathrm{B} 3 \mathrm{~S}$ & $0,276 \pm 0,03 \mathrm{bA}$ & $0,222 \pm 0,02 \mathrm{bcB}$ & $0,184 \pm 0,02 \mathrm{aB}$ \\
BAS & $0,228 \pm 0,02 \mathrm{cA}$ & $0,186 \pm 0,02 \mathrm{cB}$ & $0,164 \pm 0,02 \mathrm{aB}$ \\
PC & $0,191 \pm 0,02 \mathrm{cA}$ & $0,215 \pm 0,02 \mathrm{bcB}$ & $0,171 \pm 0,02 \mathrm{aB}$ \\
$\mathrm{AC}$ & $0,141 \pm 0,01 \mathrm{dAB}$ & $0,239 \pm 0,02 \mathrm{abA}$ & $0,185 \pm 0,02 \mathrm{aB}$ \\
\hline
\end{tabular}

BNS- Application of $1.0 \mathrm{~mL} \mathrm{~L}^{-1}$ of amino acid three days before water stress (80\%WRC); $33 \mathrm{~S}$ - Application of $1.0 \mathrm{~mL} \mathrm{~L}^{-1}$ amino acid three days before water stress (50\%WRC); BAS - Application of $1.0 \mathrm{~mL} \mathrm{~L}^{-1}$ amino acid on the day of water stress (50\% WRC); PC - Positive control (without application and 50\% WRC); AC - Absolute control (without application and 80\% WRC). Means followed by the same letter do not differ statistically in Tukey's test $(\mathrm{p} \leq 0.05)$. Uppercase letters $=$ compare lines (treatments over days). Lowercase letters $=$ compare columns (treatment per day).

Source: Authors.

The comparison between the contents of chlorophyll $\mathrm{b}$ and total chlorophyll showed reductions over the collections that cannot be attributed to water restriction as they occurred similarly in the AC treatment, a behavior also observed regarding the carotenoid contents. 
Sugar contents in the leaves showed interactions between treatments and collection days as shown in Table 3 . In the comparison among the total sugar content (TS) over the days in each treatment, the AC did not show changes, representing the natural process of TS accumulation of the cultivar in the period of evaluations. On the other hand, BNS showed increments on the fifth and eight days as a consequence of the application of the biofertilizer in plants without water restriction, an effect that was not observed in 50\%WRC, in the B3S and BAS treatments, showing reductions in TS levels, similarly to the PC.

Table 3. Sugar $\left(\mu \mathrm{g} \mathrm{g}^{-1}\right)$ of 45-day-old soybean (Glycine max) leaves, kept in pots, subjected to water stress and amino acid application in collections at 3 different days.

\section{Fifth day}

$11100 \pm 856 \mathrm{aA}$
$10980 \pm 847 \mathrm{aC}$
$11114 \pm 858 \mathrm{aC}$
$11232 \pm 867 \mathrm{aB}$
$10766 \pm 831 \mathrm{aA}$

\section{Third day}

\section{Eighth day}

(a) Total

$$
\begin{gathered}
9303 \pm 718 \mathrm{~dB} \\
26867 \pm 2074 \mathrm{aA} \\
16984 \pm 1311 \mathrm{cA} \\
22993 \pm 1775 \mathrm{bA} \\
10698 \pm 825 \mathrm{dA}
\end{gathered}
$$

$$
\begin{gathered}
4437 \pm 631 \mathrm{cA} \\
16931 \pm 2409 \mathrm{aA} \\
11264 \pm 1603 \mathrm{bA} \\
15274 \pm 2173 \mathrm{aA} \\
5614 \pm 798 \mathrm{cA}
\end{gathered}
$$

$$
\begin{aligned}
& 4414 \pm 628 \mathrm{aA} \\
& 5031 \pm 716 \mathrm{aB} \\
& 4460 \pm 634 \mathrm{aB} \\
& 5333 \pm 759 \mathrm{aB} \\
& 4695 \pm 668 \mathrm{aA}
\end{aligned}
$$

(c) Non-reducing

$\begin{array}{cccc}\text { BNS } & 4865 \pm 342 \mathrm{cB} & 6685 \pm 469 \mathrm{abA} & 7092 \pm 498 \mathrm{bA} \\ \mathrm{B} 3 \mathrm{~S} & 9936 \pm 698 \mathrm{aA} & 6613 \pm 464 \mathrm{abC} & 8060 \pm 566 \mathrm{aB} \\ \mathrm{BAS} & 5719 \pm 402 \mathrm{cC} & 6818 \pm 479 \mathrm{aB} & 8121 \pm 570 \mathrm{aA} \\ \mathrm{PC} & 7840 \pm 551 \mathrm{bA} & 5736 \pm 403 \mathrm{bC} & 6730 \pm 473 \mathrm{bA} \\ \mathrm{AC} & 5083 \pm 357 \mathrm{cB} & 5898 \pm 414 \mathrm{abAB} & 6590 \pm 463 \mathrm{bA}\end{array}$

BNS- Application of $1.0 \mathrm{~mL} \mathrm{~L}^{-1}$ of amino acid three days before water stress (80\%WRC); B3S - Application of $1.0 \mathrm{~mL} \mathrm{~L}^{-1}$ amino acid three days before water stress (50\%WRC); BAS - Application of $1.0 \mathrm{~mL} \mathrm{~L}^{-1}$ amino acid on the day of water stress (50\% WRC); PC - Positive control (without application and 50\% WRC); AC - Absolute control (without application and 80\% WRC). Means followed by the same letter do not differ statistically in Tukey's test $(\mathrm{p} \leq 0.05)$. Uppercase letters $=$ compare lines (treatments over days). Lowercase letters $=$ compare columns (treatment per day).

Source: Authors.

The comparison among TS between treatments each day, in 50\%WRC showed an increase in the levels on the third day, in treatment B3S, the greatest increase was caused by the application of biofertilizer three days before 50\%WRC. On the other hand, the reducing sugars (RS) did not vary in the BNS and AC treatments throughout the collections, while in $50 \%$ WRC, they showed reductions regardless of the treatments.

Also, the comparison among the non-reducing sugars (NRS) over the days in each treatment showed an increase in the $\mathrm{AC}$ on the eight-day in relation to the third day, while PC showed a reduction on the third day, in relation to the first and eighth days. Because these treatments are respectively the absolute and positive control, these changes cannot be attributed to water restriction. Nor can the increase in NRS of BNS during collections be attributed to the application of biofertilizer as a similar 
behavior occurred in the AC treatment. On the other hand, the comparison among the treatments each day showed that B3S had the highest content during water restriction (third day) and both B3S and BAS had the highest NRS concentrations on the eighth day, indicating that biofertilizer applications influenced the increase in NRS concentrations throughout and in the period following water restriction.

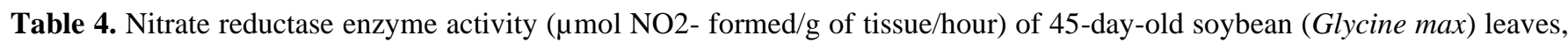
kept in pots, subjected to water stress and amino acid application in collections at 3 different days.

\begin{tabular}{cccc}
\hline & Third day & Fifth day & Eighth day \\
\hline BNS & $0,92 \pm 0,10 \mathrm{cA}$ & $0,89 \pm 0,10 \mathrm{cA}$ & $0,79 \pm 0,09 \mathrm{aA}$ \\
B3S & $1,59 \pm 0,18 \mathrm{aA}$ & $1,47 \pm 0,17 \mathrm{aA}$ & $0,93 \pm 0,11 \mathrm{aB}$ \\
BAS & $1,27 \pm 0,14 \mathrm{bA}$ & $1,15 \pm 0,13 \mathrm{bAB}$ & $0,95 \pm 0,11 \mathrm{aB}$ \\
PC & $1,32 \pm 0,15 \mathrm{bA}$ & $1,04 \pm 0,12 \mathrm{bcB}$ & $1,02 \pm 0,12 \mathrm{aB}$ \\
AC & $0,84 \pm 0,10 \mathrm{cA}$ & $0,88 \pm 0,10 \mathrm{cA}$ & $0,89 \pm 0,10 \mathrm{aA}$ \\
\hline
\end{tabular}

BNS- Application of $1.0 \mathrm{~mL} \mathrm{~L}^{-1}$ of amino acid three days before water stress (80\%WRC); B3S - Application of $1.0 \mathrm{~mL} \mathrm{~L}^{-1}$ amino acid three days before water stress (50\%WRC); BAS - Application of $1.0 \mathrm{~mL} \mathrm{~L}^{-1}$ amino acid on the day of water stress (50\% WRC); PC - Positive control (without application and 50\% WRC); AC - Absolute control (without application and 80\% WRC). Means followed by the same letter do not differ statistically in Tukey's test $(\mathrm{p} \leq 0.05)$. Uppercase letters $=$ compare lines (treatments over days). Lowercase letters $=$ compare columns (treatment per day).

Source: Authors.

Interactions were found between the factors regarding the activity of the nitrate reductase (NR) enzyme as shown in Table 4. Comparing the values over the days in each treatment, there were no changes in plants without water restriction (AC), or with the application of biofertilizer in this condition (BNS). Also, the positive control and treatments with an application of biofertilizer in 50\%WRC showed similar behavior. On the other hand, the comparison among treatments each day allowed us to observe that the application of biofertilizer three days before reaching $50 \% \mathrm{WRC}(\mathrm{B} 3 \mathrm{~S})$ promoted significant increases in NR activity during water restriction (third day) and soon after rehydration (fifth day). No differences were found in NR activity on the eighth day.

Table 5. Free amino acids ( $\mu \mathrm{g} \mathrm{g}^{-1}$ ) of 45-day-old soybean (Glycine max) leaves, kept in pots, subjected to water stress and amino acid application in collections at 3 different days.

\begin{tabular}{cccc}
\hline & Third day & Fifth day & Eighth day \\
\hline BNS & $4250,76 \pm 444,63 \mathrm{dA}$ & $4451,66 \pm 465,64 \mathrm{bcA}$ & $3225,15 \pm 337,35 \mathrm{aB}$ \\
B3S & $11909,57 \pm 1245,74 \mathrm{aA}$ & $7676 \pm 802,91 \mathrm{aB}$ & $4072,58 \pm 425,99 \mathrm{aC}$ \\
BAS & $5803,36 \pm 607,03 \mathrm{bcA}$ & $5403,44 \pm 565,2 \mathrm{bA}$ & $3698,95 \pm 386,91 \mathrm{aB}$ \\
PC & $6778,61 \pm 709,04 \mathrm{bA}$ & $4229,31 \pm 442,39 \mathrm{cB}$ & $3793,59 \pm 396,81 \mathrm{aB}$ \\
AC & $4943,39 \pm 517,08 \mathrm{cdA}$ & $3914,77 \pm 409,48 \mathrm{cB}$ & $3028,72 \pm 316,8 \mathrm{aB}$ \\
\hline
\end{tabular}

BNS- Application of $1.0 \mathrm{~mL} \mathrm{~L}^{-1}$ of amino acid three days before water stress (80\%WRC); B3S - Application of $1.0 \mathrm{~mL} \mathrm{~L}^{-1}$ amino acid three days before water stress (50\%WRC); BAS - Application of $1.0 \mathrm{~mL} \mathrm{~L}^{-1}$ amino acid on the day of water stress (50\% WRC); PC - Positive control (without application and 50\% WRC); AC - Absolute control (without application and 80\% WRC). Means followed by the same letter do not differ statistically in Tukey's test $(\mathrm{p} \leq 0.05)$. Uppercase letters $=$ compare lines (treatments over days). Lowercase letters $=$ compare columns (treatment per day).

Source: Authors.

Interactions were observed between the factors regarding the levels of total free amino acids (FA) as shown in Table 5. Comparing the values over the days showed that BNS did not show any changes, PC and AC showed similar behavior, with 
a reduction in FA on the eighth day, and both B3S and BAS showed increases on the fifth day and a reduction on the eight in relation to the third day. On the other hand, comparing the treatments each day, B3S stood out with the highest values of FA on the third and fifth days, with increases of respectively $75 \%$ and $81 \%$ compared to plants subjected to water restriction (PC). There was no difference between treatments on the eighth day.

Interactions were found between the factors regarding the proline content (PR) in the leaves as shown in Table 6. The comparison among the values over the days showed that no changes occurred on BNS, nevertheless, B3S and BAS showed increases on the fifth day compared to the third and the eighth, while PC and AC showed a decrease on the eighth in relation to the third, a behavior that cannot be attributed to water restriction as it occurred in both controls. Comparing the treatments each day showed that on the third and fifth days, B3S showed the highest levels of PR, followed by BAS. The effects of biofertilizer on PR accumulation in 50\%WRC were very significant compared to PC, with an increase of $194 \%$ in treatment $\mathrm{B} 3 \mathrm{~S}$ and $115 \%$ in treatment BAS on the third day and $544 \%$ in treatment B3S and 304\% in BAS treatment on the eighth day

Table 6. Proline $\left(\mu \mathrm{g} \mathrm{g}^{-1}\right)$ of 45-day-old soybean (Glycine max) leaves, kept in pots, subjected to water stress and amino acid application in collections at 3 different days.

\begin{tabular}{cccc}
\hline & Third day & Fifth day & Eighth day \\
\hline BNS & $4,63 \pm 1,14 \mathrm{cA}$ & $5,47 \pm 1,34 \mathrm{cA}$ & $2,37 \pm 0,58 \mathrm{aA}$ \\
B3S & $23,68 \pm 5,81 \mathrm{aB}$ & $44,91 \pm 11,02 \mathrm{aA}$ & $3,39 \pm 0,83 \mathrm{aC}$ \\
BAS & $17,29 \pm 4,24 \mathrm{bB}$ & $28,2 \pm 6,92 \mathrm{bA}$ & $4,01 \pm 0,98 \mathrm{aC}$ \\
PC & $8,03 \pm 1,3 \mathrm{cA}$ & $6,97 \pm 1,71 \mathrm{cAB}$ & $1,48 \pm 0,36 \mathrm{aB}$ \\
AC & $5,28 \pm 1,97 \mathrm{cA}$ & $4,24 \pm 1,04 \mathrm{cAB}$ & $2,55 \pm 0,63 \mathrm{aB}$ \\
\hline
\end{tabular}

BNS- Application of $1.0 \mathrm{~mL} \mathrm{~L}^{-1}$ of amino acid three days before water stress (80\%WRC); B3S - Application of $1.0 \mathrm{~mL} \mathrm{~L}^{-1}$ amino acid three days before water stress (50\%WRC); BAS - Application of $1.0 \mathrm{~mL} \mathrm{~L}^{-1}$ amino acid on the day of water stress (50\% WRC); PC - Positive control (without application and 50\% WRC); AC - Absolute control (without application and 80\% WRC). Means followed by the same letter do not differ statistically in Tukey's test $(\mathrm{p} \leq 0.05)$. Uppercase letters $=$ compare lines (treatments over days). Lowercase letters $=$ compare columns (treatment per day).

Source: Authors.

Comparing the values of lipid peroxidation (LP) over the days as shown in Table 7, a variable that expresses the activity of reactive oxygen species (ROS), showed an increase in BNS and AC treatments, a reduction in B3S and PC treatments between the third and fifth, and increase on the fifth day in relation to the third and eight days in the treatment, behaviors during the collection period that are difficult to be related to the treatments and water restriction or rehydration.

On the other hand, by comparing the treatments each day it was found that on the third day the PC had the highest value, indicating the action of ROS in $50 \% \mathrm{WRC}$, while BAS showed a reduction in LP equivalent to B3S in relation to the PC treatment, which in turn, showed values equivalent to BNS and AC, indicating that the application of biofertilizer three days before 50\%WRC reduced the action of ROS at the level of treatments without water restriction. The reductions in LP in treatments B3S and BAS compared to PC were $27 \%$ and $19 \%$, respectively.

Again, on the fifth day, PC had the highest LP value, this time equivalent to BAS, indicating that the application of biofertilizer under water restriction was not efficient in reducing the effects of ROS on the day following rehydration, unlike B3S, which once more presented values equivalent to treatments without water restriction, which was $18 \%$ lower than PC. On the eighth day, LP values were equivalent between treatments, with the statistical difference in B3S being $27 \%$ lower than PC.

The function of the enzymes peroxidase (POD), superoxide dismutase (SOD) and catalase (CAT) is degrading ROS, mitigating oxidative stress by reducing lipid peroxidation. The activity of POD, SOD, and CAT are shown in Table 7.

It could be seen through the comparison among the POD values over the days that BNS, AC, and PC did not change, while B3S showed an increase on the fifth day and a reduction on the eighth day compared to the third. Also, BAS showed an 
increase on the fifth day in relation to the third and eighth days. These changes in treatments B3S and BAS refer to the effect of biofertilizer applications, which can be better identified by comparing the treatments at each day.

Table 7. (a) Lipid peroxidation (nmol thiobarbituric acid reactive substances/g fresh mass), (b) peroxidase (POD, $\mu$ mol purpurogaline $\mathrm{min}^{-1} \mathrm{mg}^{-1}$ protein), (c) superoxide demutase enzyme activity ( SOD, $\mathrm{U} \mathrm{mg}^{-1}$ protein), (d) catalase (CAT, $\mu$ Kat $\mu \mathrm{g}^{-1}$ protein $\left.\min ^{-1}\right)$.

$\begin{array}{lll}\text { Third day } & \text { Fifth day } & \text { Eighth day }\end{array}$

\section{(a) Lipid peroxidation}

$\begin{array}{cccc}\text { BNS } & 26,06 \pm 3 \mathrm{cB} & 37,74 \pm 4,35 \mathrm{bcA} & 31,03 \pm 3,57 \mathrm{abAB} \\ \text { B3S } & 32,26 \pm 3,72 \mathrm{bcA} & 37,7 \pm 4,34 \mathrm{bcA} & 24,94 \pm 2,87 \mathrm{bB} \\ \text { BAS } & 35,87 \pm 4,13 \mathrm{bB} & 44,79 \pm 5,16 \mathrm{abA} & 31,39 \pm 3,62 \mathrm{abB} \\ \text { PC } & 44,64 \pm 5,14 \mathrm{aA} & 46,02 \pm 5,3 \mathrm{aA} & 34,52 \pm 3,98 \mathrm{aB} \\ \text { AC } & 26,97 \pm 3,11 \mathrm{cB} & 35,35 \pm 4,07 \mathrm{cA} & 36,51 \pm 4,21 \mathrm{aA}\end{array}$

\section{(b) Peroxidase}

$\begin{array}{cccc}\text { BNS } & 10,09 \pm 1,58 \mathrm{bA} & 13,21 \pm 2,06 \mathrm{bA} & 10,59 \pm 1,65 \mathrm{bA} \\ \text { B3S } & 20,86 \pm 3,26 \mathrm{aB} & 30,63 \pm 4,78 \mathrm{aA} & 15,47 \pm 2,41 \mathrm{abC} \\ \text { BAS } & 14,97 \pm 2,34 \mathrm{bB} & 27,94 \pm 4,36 \mathrm{aA} & 15,26 \pm 2,38 \mathrm{abB} \\ \text { PC } & 14,98 \pm 2,34 \mathrm{bA} & 18,44 \pm 2,88 \mathrm{bA} & 19,41 \pm 3,03 \mathrm{aA} \\ \text { AC } & 14,57 \pm 2,27 \mathrm{bA} & 16,03 \pm 2,5 \mathrm{bA} & 15,31 \pm 2,39 \mathrm{abA}\end{array}$

(c) Superoxide dismutase

$\begin{array}{cccc}\text { BNS } & 30042,57 \pm 5224,4 \mathrm{aA} & 31105,28 \pm 5409,21 \mathrm{aA} & 29181,57 \pm 0 \mathrm{abA} \\ \mathrm{B} 3 \mathrm{~S} & 22137,45 \pm 3849,7 \mathrm{abA} & 18925,09 \pm 3291,07 \mathrm{bA} & 24832,15 \pm 0 \mathrm{bA} \\ \text { BAS } & 27334,33 \pm 4753,44 \mathrm{aB} & 23274,75 \pm 4047,48 \mathrm{abB} & 36900,5 \pm 0 \mathrm{aA} \\ \text { PC } & 17464,68 \pm 3037,11 \mathrm{bA} & 18854,85 \pm 3278,86 \mathrm{bA} & 22973,74 \pm 0 \mathrm{bA} \\ \text { AC } & 23311,53 \pm 4053,88 \mathrm{abA} & 26092,59 \pm 4537,5 \mathrm{abA} & 27177,48 \pm 0 \mathrm{bA}\end{array}$

(d) Catalase

\begin{tabular}{|c|c|c|c|}
\hline BNS & $1,03 \pm 0,76 \mathrm{aA}$ & $1,5 \pm 1,11 \mathrm{aA}$ & $2,94 \pm 2,18 \mathrm{aA}$ \\
\hline B3S & $1,93 \pm 1,43 \mathrm{aA}$ & $0,76 \pm 0,56 \mathrm{aA}$ & $3,88 \pm 2,87 \mathrm{aA}$ \\
\hline BAS & $4,28 \pm 3,17 \mathrm{aA}$ & $2,23 \pm 1,65 \mathrm{aA}$ & $5,66 \pm 4,19 \mathrm{aA}$ \\
\hline $\mathrm{PC}$ & $2,28 \pm 1,69 \mathrm{aA}$ & $1,8 \pm 1,33 \mathrm{aA}$ & $1,55 \pm 1,15 \mathrm{aA}$ \\
\hline $\mathrm{AC}$ & $2,74 \pm 2,03 \mathrm{aA}$ & $1,7 \pm 1,26 \mathrm{aA}$ & $2,67 \pm 1,98 \mathrm{aA}$ \\
\hline
\end{tabular}

BNS- Application of $1.0 \mathrm{~mL} \mathrm{~L}^{-1}$ of amino acid three days before water stress (80\%WRC); B3S - Application of $1.0 \mathrm{~mL} \mathrm{~L}^{-1}$ amino acid three days before water stress (50\%WRC); BAS - Application of $1.0 \mathrm{~mL} \mathrm{~L}^{-1}$ amino acid on the day of water stress (50\% WRC); PC - Positive control (without application and 50\% WRC); AC - Absolute control (without application and 80\% WRC). Means followed by the same letter do not differ statistically in Tukey's test $(\mathrm{p} \leq 0.05)$. Uppercase letters $=$ compare lines (treatments over days). Lowercase letters $=$ compare columns (treatment per day).

Source: Authors.

It was found on the third day, the highest POD activity in B3S, differing from the other treatments. Compared to PC treatment, the increase was $39 \%$, indicating that the application of biofertilizer three days before 50\%WRC stimulates enzyme activity under water restriction. On the fifth day, B3S and BAS showed a higher POD activity than the other treatments, 
indicating that the effect of biofertilizer applications maintained a greater POD activity even after rehydration, in treatments B3S and BAS, showing increments of $66 \%$ and $51 \%$, respectively, in relation to PC treatment. On the eighth day, the treatments showed equivalent behavior.

By comparing the SOD values over the days, an alteration was observed only in the BAS treatment, which on the eighth day showed an increase in enzyme activity in relation to the third and fifth days. The comparisons among the treatments on each day, on the third day, BAS and BNS showed SOD activity higher than the positive control (PC), in which BAS showed a value 56\% higher than PC. On the fifth day, the differences between treatments are not well defined, with BNS being equivalent to BAS and AC, however, they did not differ from B3S and PC. On the eighth day, BAS repeated the same behavior observed on the third day, with the application of biofertilizer in 50\%WRC showing an increase of $60 \%$ in SOD activity compared to PC treatment.

The CAT enzyme activity did not change over the days or among treatments on each day as shown in Table 7.

\section{Discussion}

Water stress causes stomatal closure, which reduces transpiration and inhibits $\mathrm{CO}_{2}$ assimilation, triggering several events, such as a decrease in the photosynthesis, leaf expansion, and promotion of early senescence (Farooq et al., 2009). For treatments with 50\%WRC, it is possible to see an increase in SR. Tests also carried out on soybean subjected to water stress using polyethylene glycol (PEG) showed a reduction in a progressive stomatal conductance due to the reduction in water availability, especially in the early stages of development (Basal et al., 2020). The application of biofertilizer acted in stomatal regulation so that treatments with $50 \% \mathrm{WRC}$ and with application had lower SR, therefore greater stomatal opening for gas exchange. Treatment BAS had the lowest SR values since the beginning of $50 \%$ WRC, indicating that the effect of the biofertilizer was immediate in reducing SR.

The increment in the variables TS, RS and NRS on the third day in plants that were at 50\%WRC compared to plants without water restriction demonstrates an adaptation mechanism of soybean under water restriction conditions. Under stress, plants accumulate sugars as a form of defense, acting in the perception, signaling, and regulation of gene expression, ensuring osmotic adjustment responses, and maintaining cellular energy through carbon partition (Saddhe et al., 2020). The osmotic adjustment takes place so that the cell osmotic potential is reduced, therefore contributing to the maintenance of turgor. Through osmotic adjustment, organelles and cytoplasmic activities are preserved, maintaining growth and development (Farooq et al., 2009). Other authors have also reported the increase in soluble sugars in soybean leaves subjected to water stress as part of the osmotic adjustment process (Liu et al., 2004; Dong et al., 2019; Du et al., 2020).

On the third day, besides the increment in TS in all treatments that were in $50 \%$ WRC compared to treatments in $80 \% \mathrm{WRC}$, the B3S treatment showed the highest value as an effect of the application of biofertilizer, therefore contributing to osmotic adjustment and damage reduction caused by water restriction. A similar effect was observed by (Zhang et al., 2017) with soil application of glutamic acid in Brassica rapa with an increase in the soluble sugar content compared to treatments without amino acid application.

Non-reducing sugars, specifically sucrose, in plants subjected to water stress can act as a protective agent related to antioxidant activities, such as the elimination of reactive oxygen species (ROS) (Bolouri-Moghaddam, 2010). The application of biofertilizer increased the levels of NRS, improving the antioxidant activity of the plants, with an increase in the third collection with 50\%WRC, and after the rehydration period, indicating a prolonged effect on stress mitigation, considering that even after the stress period plants can show the effects of oxidative damage caused by water restriction (Zhang et al., 2004). 
The enzyme NR is a key for the acquisition of nitric nitrogen by plants. It is involved in the regulation of stomatal opening and activation of antioxidant enzymes modulated by nitric oxide (Bajguz, 2013; Chamizu-Ampudia et al., 2017). Nitric oxide is a signaling molecule in plants promoting changes in antioxidant systems as it is a direct ROS-scavenger as triggers the expression of antioxidant genes or activates antioxidant enzymes (Groß et al., 2013). Thus, the increase in NR with the biofertilizer application becomes another mechanism for the plant to adapt to water stress, helping to eliminate ROS. Previous works have demonstrated the increase of the NR enzyme in plants that received applications of L-glutamic acid, such as potatoes (Röder et al., 2018) and onion (Cao et al., 2010).

The amino acid L-glutamic acid is the first compound produced in the nitrogen assimilation, forming glutamine, glutamate, and asparagine, and from them, the nitrogen transport throughout the plant, in addition to the synthesis of chlorophyll and other amino acids (Ford \& Lea, 2007), explaining the results of increased FA in plants in the B3S treatment, which indicates the absorption and metabolization of the biofertilizer, an effect already reported by (Gemin et al., 2019) when reporting the increase of FA in Chinese cabbage with foliar applications of L-glutamic acid.

The accumulation of free amino acids associated with stress is part of a process that contributes to osmotic adjustment. These amino acids, as well as the also accumulated soluble sugars, help to prevent cell dehydration and maintain the structure and function of cell membranes (Zhong et al., 2018). Soybean plants subjected to water stress showed an increase in FA content (Batista-Silva et al., 2018), an effect also observed at the beginning of water restriction in B3S and PC treatments, with increased FA contents compared to AC and BNS without water restriction, but B3S with higher FA content as a beneficial effect of biofertilizer application.

Proline (PR) is an important osmolyte for osmotic adjustment under water stress conditions, in addition to being a stabilizer of cell structures with the elimination of ROS and alleviating cytoplasmic acidity, maintaining appropriate levels of $\mathrm{NADP}^{+} / \mathrm{NADPH}$ for metabolic processes (Gill \& Tuteja, 2010; Hayat et al., 2012). Plants synthesize PR from glutamine in their leaves (Mahajan \&Tuteja, 2005).

The application of biofertilizer contributed to the increase in PR levels in the 50\%WRC treatments, with increases in treatments B3S and BAS, being higher in B3S, therefore indicating that the time of application interfered with the PR accumulation. Similar results of PR accumulation in soybean plants under water deficit were found with the application of Glutamate (Teixeira et al., 2020).

Plants subjected to water stress have increased ROS. Also, one of the consequences is lipid peroxidation, which aggravates oxidative stress by producing lipid-derived radicals, which react and damage proteins, DNA and can cause cell death (Gill \& Tuteja, 2010; Sharma et al., 2012). Thus, lower values of lipid peroxidation (PL) can be related to the mitigation of the stress effects. Biofertilizer application promoted the elimination of ROS and, therefore, drops in LP values in treatments B3S and BAS. (Xu et al., 2020) also found a reduction in LP values under water stress conditions in Brassica rapa plants with the application of poly- $\gamma$-glutamic acid.

This effect in the reduction of LP can be attributed to the increases in PR, and the enzymes POD and SOD, potential ROS scavengers, due to the applications of the biofertilizer.

As a manner of antioxidant defense, plants produce enzymes that act in the elimination of e ROS, such as peroxidase (POD), superoxide dismutase (SOD), and catalase (CAT) (Talbi et al., 2015). Thus, finding substances that increase the activity of these enzymes is a way to mitigate the damage caused by water stress. The application of biofertilizer promoted an increase in POD and SOD in soybean plants at 50\%WRC. Therefore, the application of biofertilizer was efficient in mitigating the oxidative effects of soybean plants subjected to water restriction. 


\section{Conclusion}

The biofertilizer containing $25 \%$ of the amino acid L-glutamic acid enhanced stomatal conductance and increased levels of sugars, amino acids, proline, nitrate reductase enzyme, and antioxidant enzymes, reducing lipid peroxidation in soybean plants subjected to water restriction. Future studies must be carried out using biofertilizer amino acid L-glutamic acid to mitigate the deleterious effects loss in large cultures caused by abiotic stresses (e.g. saline stress).

\section{References}

Anda, A., Soós, G., Menyhárt, L., Kucserka, T. \& Simon, B. (2020). Yield features of two soybean varieties under different water supplies and field conditions. Field Crops Research, 245(107673). https://doi.org/10.1016/j.fcr.2019.107673

Bajguz, A. (2014). Nitric oxide: role in plants under abiotic stress. Physiological Mechanisms and Adaptation Strategies in Plants Under Changing Environment. Springer, 137-159.

Basal, O., Szabó, A. \& Veres, S. (2020). Physiology of soybean as affected by PEG-induced drought stress. Current Plant Biology, 22 (100135). https://doi.org/10.1016/j.cpb.2020.100135

Bates, L. S., Waldern, R. P. \& Teare, I. D. (1973). Rapid determination of free proline for water stress studies. Plant and Soil, $39,205-207$.

Batista-Silva, W., Heinemann, B., Rugen, N., Nunes-Nesi, A., Araújo, W.L., Braun, H. P. \& Hildebrandt, T. M. (2019). The Role of Amino Acid Metabolism during Abiotic Stress Release. Plant Cell Environment, 42(5), 1630-1644. https://doi.org/10.1111/pce.13518

Bolouri-Moghaddam M. R., Le Roy K., Xiang L., Rolland F. \& Van den Ende W. (2010). Sugar signalling and antioxidant network connections in plant cells. The FEBS Journal, 277(9), 2022-2037. https://doi.org/10.1111/j.1742-4658.2010.07633.x

Bradford, M. M. (1976). A rapid and sensitive method for the quantitation of microgram quantities of protein utilizing the principle of protein-dye binding. Analytical Biochemistry, 72(7), 248-254.

Brasil. Ministério da Agricultura, Pecuária e Abastecimento, 2020. Instrução normativa no 61 , 474 de 8 de julho de 2020 . Diário Oficial da União. https://www.in.gov.br/web/dou/-/instrucao475normativa-n-61-de-8-de-julho-de2020

Cao, Y.P., Gao, Z.K., Li, J.T., Xu, G.H. \& Wang, M. (2010). Effects of extraneous glutamic acid on nitrate contents and quality of chinese chive. Acta Horticulturae, 856, 91-98. https://doi.org/10.17660/ActaHortic.2010.856.11

Chamizo-Ampudia, A., Sanz-Luque, E., Llamas, A., Galvan, A. \& Fernandez, E. (2017) Nitrate reductase regulates plant nitric oxide homeostasis. Trends in Plant Science, 22(2), 163-174.

Devi, S. R. \& Prasad, M. N. V. (1998) Copper toxicity in Ceratophyllum demersum L. (Coontail), a free floating macrophyte: response of antioxidant enzymes and antioxidants. Plant Science, 138(2), 157-65.

Dong, S., Jiang, Y., Dong, Y., Wang, L., Wang, W., Ma, Z., Yan, C., Ma, C. \& Liu, L. (2019) A study on soybean responses to drought stress and rehydration. Saudi Journal of Biological Sciences, 26(8), 2006-2017. https://doi.org/10.1016/j.sjbs.2019.08.005

Du, Y., Zhao, Q., Chen, L., Yao, X., Zhang, W., Zhang, B. \& Xie, F. (2020). Effect of drought stress on sugar metabolism in leaves and roots of soybean seedlings. Plant Physiology and Biochemistry, 146,1-12. doi:10.1016/j.plaphy.2019.11.003.

Farooq M., Wahid A., Kobayashi N., Fujita D. \& Basra S. M. A. (2009). Plant drought stress: effects, mechanisms and management. Sustainable Agriculture., 29, 185-212. https://doi.org/10.1007/978-90-481-2666-8_12

Ferreira, D. F. (2019). Sisvar: a computer analysis system to fixed effects split plot type designs. Revista Brasileira de Biometria, 37, 529-535. https://doi.org/10.28951/rbb.v37i4.450

Forde B. G. \& Lea P. J. (2007). Glutamate in plants: metabolism, regulation and signalling. Journal of Experimental Biology, 58(9), 2339-2358. doi:10.1093/jxb/erm 121

Gemin, L. G., Mógor, A. F., Mógor, G., Röder, C. \& Szilagyi-Zecchin V. J. (2018). Changes in growth and concentration of amino acids in Chinese cabbage seedlings using bacterial fermented broth. Idesia, 36, 7-13. http://dx.doi.org/10.4067/S0718-34292018000100007

Giannopolitis, C. N. \& Ries, S. K. (1977). Superoxide dismutases: I. Occurrence in higher plants. Plant physiology, 59(2), 309-314.

Gill, S. S. \& Tuteja, N. (2010). Reactive oxygen species and antioxidant machinery in abiotic stress tolerance in crop plants. Plant Physiology and Biochemistry, 48(12), 909-930. doi: 10.1016/j.plaphy.2010.08.016

Groß, F., Durner, J., \& Gaupels, F. (2013). Nitric oxide, antioxidants and prooxidants in plant defence responses. Frontiers in Plant Science, 4, 419. doi: 10.3389/fpls.2013.00419

Hayat, S., Hayat, Q., Alyemeni, M.N., Wani, A.S., Pichtel, J. \& Ahmad, A. (2012). Role of proline under changing environments. Plant Signaling and Behavior, 7(11),1456-1466. https://doi.org/10.4161/psb.21949 
Heath, R. L. \& Packer, L. (1968) Photoperoxidation in isolated chloroplasts I. Kinetic and stoichiometry of fatty acid peroxidation. Archives of biochemistry and biophysics, 125(1), 189-198.

Jaworski, E. K. (1971). Nitrate reductase assay in intact plant tissues. Biochemical and Biophysical. Research Communications New York, 43(6), 1274-1279.

Lichtenthaler, H. K. (1987). Chlorophylls and carotenoids: Pigments of photosynthetic biomembranes. Methods in Enzymology, 148, $350-382$.

Liu, F., Jensen, C. R. \& Andersen, M. N. (2004). Drought stress effect on carbohydrate concentration in soybean leaves and pods during early reproductive development: Its implication in altering pod set. Field Crops Research, 86(1), 1-13. doi: 10.1016/S0378-4290(03)00165-5

Liu, S., Zhang, M., Feng, F. \& Tian, Z. (2020). Toward a “Green Revolution', for Soybean. Molecular Plant, 13(5), 688-697. doi: 10.1016/j.molp.2020.03.002.

Magné, C. \& Larher, F. (1992) High sugar content interferes with colorimetric determination of amino acids and free proline. Analytical Biochemistry, 200(1), $115-118$.

Mahajan S. \& Tuteja N. (2005) Cold, salinity and drought stresses: na overview. Arch. Biochem. Biophys. 444(2), 139-158. doi: 10.1016/j.abb.2005.10.018.

Maldonade, I. R., Carvaho, P. G. B. \& Ferreira, N. A. (2013) Protocolo para a Determinação de Açucares Totais em Hortaliças pelo Método de DNS. Comunicado Técnico: EMBRAPA, 85, 1-4.

McDermitt, D. K. (1990). Sources of Error in the Estimation of Stomatal Conductance and Transpiration from Porometer Data. HortScience, 25(12), 15381548. doi: 10.21273/hortsci.25.12.1538

Mousavi-Derazmahalleh, M., Bayer, P.E., Hane, J.K., Babu, V., Nguyen, H.T., Nelson, M.N., Erskine, W., Varshney, R.K., Papa, R. \& Edwards, D. (2018) Adapting legume crops to climate change using genomic approaches. Plant Cell Environ.. 42(1), 6-19. https://doi.org/10.1111/pce.13203

Peixoto, H. P. P., Cambraia, J., Sant'ana, R., Mosquim, P. R. \& Moreira, A. M. (1999). Aluminium effects on lipid peroxidation and the activities of enzymes of oxidative metabolism in sorghum. Revista Brasileira de Fisiologia Vegetal, 11(3), 137-143.

Pereira, A. S., Shitsuka, D. M., Parreira, F. J., \& Shitsuka, R. (2018). Metodologia da Pesquisa científica. [e-book]. Santa Maria. Ed. UAB/NTE/UFSM. Available in: https://repositorio.ufsm.br/bitstream/handle/1/15824/Lic_Computacao_Metodologia-Pesquisa-Cientifica.pdf?sequence=1. Access on: 18 Agust 2021.

Pompelli, M. P., França, S. C., Tigre, R. C., Oliveira, M. T., Sacilot, M. \& Pereira, E. C. (2013). Spectrophotometric determinations of chloroplastidic pigments in acetone, ethanol and dimethylsulphoxide. Revista Brasileira de Biociências, 11(1), 52-58.

Rhodes D. \& Handa S. (1989). Amino acid metabolism in relation to osmotic adjustment in plant cells. In Cherry J. H. (ed) Environmental stress in plants, biochemical and physiological mechanisms. Ecological Sciences, 19, 41-62.

Röder, C., Mógor, A. F., Szilagyi-Zecchin, V. J., Gemin, L. G., \& Mógor, G. (2018). Potato yield and metabolic changes by use of biofertilizer containing Lglutamic acid. Comunicata Scientiae, 9(2), 211-218. doi: 10.14295/CS.v9i2.2564

Saddhe, A. A., Manuka, R. \& Suprasanna, P. (2020) Plant sugars: Homeostasis and transport under abiotic stress in plants. Physiologia Plantarum,171(4), 739-755. https://doi.org/10.1111/ppl.13283.

Sharma, P., Jha, A. B., Dubey, R. S. \& Pessarakli, M. (2012). Reactive oxygen species, oxidative damage, and antioxidative defense mechanism in plants under stressful conditions. Journal of Botany. 2012, 217037. doi: 10.1155/2012/217037

Silva, T. R da., Costa, M. L. A. da, Farias, L. R. A., Santos, M. A. dos, Rocha, J. J. de L. \& Silva, J. V. (2021) Fatores abióticos no crescimento e florescimento das plantas. Research, Society and Development 10(4). doi: http://dx.doi.org/10.33448/rsd-v10i4.13817

Taiz, L.; Zeiger, E., Moller I. M. \& Murphy, A. (2017) Fisiologia e desenvolvimento vegetal. 6. ed. Porto Alegre: Artmed, p. 888

Talbi, S., Romero-Puertas, M. C., Hernández, A., Terrón, L., Ferchichi, A. \& Sandalio, L. M. (2015). Drought tolerance in a saharian plant Oudneya africana: role of antioxidant defences. Environmental and Experimental Botany, 111, 114-126. doi: 10.1016/j.envexpbot.2014.11.004

Teisseire, H. \& Guy, V. (2000). Copper-induced changes in antioxidant enzymes activities in fronds of duckweed (Lemna minor). Plant science, 153, 65-72.

Teixeira, W.F., Soares, L.H., Fagan, E.B., Mello, S.C., Reichardt, K. \& Dourado-Neto, D. (2020). Amino acids as stress reducers in soybean plant growth under different water-deficit conditions. Journal of Plant Growth Regulation, 39, 905-919. https://doi.org/10.1007/s00344-019-10032-z

Trenberth, K. E., Dai, A., Van Der Schrier, G., Jones, P. D., Barichivich, J., Briffa, K. R., \& Sheffield, J. (2014). Global warming and changes in drought. Nature Climate Change, 4, 17-22. https://doi.org/10.1038/nclimate2067

Winters, A. L., Lloyd, J. D., Jones, R. \& Merry, R. J. (2002) Evaluation of a rapid method for estimating free amino acids in silages. Animal feed science and technology, 99, 177-187.

Xu, Z., Ma, J., Lei, P., Wang, Q., Feng, X. \& Xu, H. (2020). Poly- $\gamma$-glutamic acid induces system tolerance to drought stress by promoting abscisic acid accumulation in Brassica napus L. Scientific Reports, 10(252). doi: 10.1038/s41598-019-57190-4

Xu, Z., Zhou, G., \& Shimizu, H. (2010). Plant responses to drought and rewatering. Plant Signaling \& Behavior, 5(6), 649-654. doi: 10.4161/psb.5.6.11398

Zhang, F., Guo, J. K., Yang, Y. L., He, W. L. \& Zhang, L. X. (2004). Changes in the pattern of antioxidant enzymes in wheat exposed to water deficit and rewatering. Acta Physiologiae Plantarum, 26, 345-352. 
Research, Society and Development, v. 10, n. 11, e11101119377, 2021

(CC BY 4.0) | ISSN 2525-3409 | DOI: http://dx.doi.org/10.33448/rsd-v10i11.19377

Zhang, L., Yang X., Gao D., Wang L., Li J., Zhanbo Wei Z. \& Shi Y. (2017). Effects of poly- $\gamma$ glutamic acid ( $\gamma$-PGA) on plant growth and its distribution in a controlled plant-soil system. Scientific Reports, 7, 1-13. https://doi.org/10.1038/s41598-017-06248-2

Zhong, C., Cao, X., Bai, Z., Zhang, J., Zhu, L., Huang, J. \& Jin, Q. (2018). Nitrogen metabolism correlates with the acclimation of photosynthesis to shortterm water stress in rice (Oryza sativa L.). Plant Physiology and Biochemistry, 125, 52-62. doi: 10.1016/j.plaphy.2018.01.024. 